\title{
ANALISIS MANIPULASI SPLICING PADA CITRA DIGITAL MENGGUNAKAN METODE DETEKSI TEPI BLOCK JPEG TERKOMPRESI
}

\author{
Muhamad Masjun Efendi ${ }^{1}$, Sofiansyah Fadli², M. Hizbul Wathan ${ }^{3}$
}

STMIK Mataram ${ }^{1}$

STMIK Lombok ${ }^{2}$

Universitas Atma Jaya Yogyakarta ${ }^{3}$

creativepio@gmail.com ${ }^{1}$

\begin{abstract}
Abstrak - Citra digital semakin mudah untuk dimanipulasi dan diedit. Sering kali sebelum citra tersebut dipublikasi dilakukan proses manipulasi. Salah satu bentuk manipulasi citra adalah splicing. Manipulasi ini dilakukan dengan menduplikasi bagian tertentu dari satu citra atau lebih dan meletakkannya pada bagian tertentu di citra target (copy-move pada citra yang berbeda). Tujuan dari manipulasi splicing ini adalah untuk menambah objek dalam citra, contohnya meletakkan suatu objek pada citra target yang seolah-olah objek tersebut berada disana.Pada penelitian ini manipulasi citra jenis ini dideteksi menggunakan metode deteksi tepi block JPEG terkompresi. Metode ini mampu mendeteksi objek citra yang dimanipulasi dengan baik dan akurat.
\end{abstract}

Kata Kunci - citra digital, deteksi tepi, manipulasi citra, splicing

\section{Pendahuluan}

Citra atau gambar digital digunakan sebagai media komunikasi untuk penyampaian informasi. Keaslian dari suatu citra memiliki peran penting dalam banyak bidang, termasuk penyelidikan forensik, investigasi kriminal, sistem surveilans, badan intelijen, pencitraan medis dan jurnalisme (Charpe, 2015). Dengan semakin canggihnya perangkat lunak pengolahan citra membuat proses manipulasi citra menjadi lebih mudah dan cepat dilakukan, sehingga menimbulkan hasrat seseorang untuk melakukan manipulasi citra dan sering kali sebelum citra tersebut dipublikasi dilakukan proses manipulasi apalagi dengan dukungan fasilitas internet serta adanya berbagai media sosial sebagai sarana penyebaran membuat citra yang telah dimanipulasi sangat mudah tersebar ke publik (Kashyap, 2017). Walapun kegiatan ini adalah hal yang lumrah dilakukan, namun terkadang merugikan orang lain dan sekaligus juga merupakan penipuan publik akan kebenaran citra tersebut. Dalam praktiknya Teknik untuk memanipulasi citra terutama foto sering disalahgunakan untuk kepentingan tertentu, sebagai contoh untuk memberikan suatu informasi palsu dan provokasi yang dapat merugikan individu, seperti kasus sindikat Saracen yang melakukan penyebaran kebencian dan fitnah dengan menggunakan isu SARA di media sosial (Tim Okezone, 2017).

Contoh dibidang hukum, terkadang suatu citra atau gambar dijadikan barang bukti dipengadilan. Jika sebuah citra yang diajukan ke pengadilan diketahui sudah dimanipulasi, walaupun hanya menambahkan titik saja di citra tersebut, maka integritas dan validitas dari citra tersebut hilang dan sudah tidak bisa lagi digunakan sebagai barang bukti dipengadilan (Kresnha, 2016).

Ada beberapa tujuan dalam melakukan manpulasi, seperti humor, hiburan, sensasi, ekonomi, pendidikan atau yang lebih ekstrim lagi adalah untuk menebarkan kebencian dan fitnah (Wicaksana, 2106).

Image Forgery merupakan tindakan pemalsuan citra yang dilakukan secara illegal. Ada beberapa jenis pemalsuan citra, diantaranya cloning, rotating, scaling, retouching, copy-move, splicing dll, tapi yang paling umum dilakukan adalah splicing. splicing yaitu menduplikasi bagian tertentu dari satu citra atau lebih dan meletakkannya pada bagian tertentu di citra target (copy-move pada citra yang berbeda) (Tembe, 2017).

Pengolahan citra digital merupakan proses yang bertujuan untuk memanipulasi dan menganalisis citra dengan bantuan komputer ataupun dengan perangkat lainnya. Salah satu Teknik pengolahan citra yang digunakan adalah deteksi tepi (edge detection). Deteksi tepi (Edge detection) adalah operasi yang dijalankan untuk mendeteksi garis tepi (edge) yang membatasi dua wilayah citra homogen yang memiliki tingkat kecerahan yang berbeda. Sedangkan tepi (edge) adalah daerah dimana intensitas piksel bergerak dari nilai yang rendah ke nilai yang tinggi atau sebaliknya. Deteksi tepi pada sebuah citra digital merupakan proses untuk mencari perbedaan intensitas yang menyatakan batas batas suatu objek (sub citra) dalam keseluruhan citra digital.

Citra atau gambar adalah salah satu komponen yang berperan penting sebagai bentuk 
media informasi berupa citra visual. Citra dari sudut pandang matematis, merupakan fungsi menerus (continue) dari intensitas cahaya pada bidang dua dimensi $f(x, y)$, dengan $x$ dan y adalah koordinat spasial dan amplitudo f pada pasangan koordinat $(x, y)$ yang disebut intensitas atau derajat keabuan citra pada titik tersebut. Jika $(x, y)$ dan $f$ semuanya berhingga dan nilainya diskrit, citra tersebut merupakan citra digital. Tujuan deteksi tepi ini yaitu untuk meningkatkan penampakan garis batas suatu daerah atau objek didalam citra. Proses deteksi tepi dilakukan dengan mencari lokasi intensitas piksel piksel yang berdekatan suatu titik (x,y) dikatakan sebagai tepi (edge) dari suatu citra.

Secara umum citra yang beredar didunia digital khususnya internet adalah citra dengan format JPEG hal ini dikarenakan JPEG memiliki standar untuk pertukaran metadata dikenal dengan format JFIF (JPEG File Interchange Format) yang memungkinkan JPEG dapat dipertukarkan antar platform dan aplikas (Li, 2015). Kompresi Citra adalah aplikasi kompresi data yang dilakukan terhadap citra digital dengan tujuan untuk mengurangi redundansi dari datadata yang terdapat dalam citra sehingga dapat disimpan atau ditransmisikan secara efisien. Ciri khas kompresi JPEG adalah kompresi jenis block ukuran 8x8 piksel, hal ini menyebabkan adanya yang dikenal dengan istilah block artifact tepi block JPEG terkompresi (Lou, 2012).

Karena pentingnya pengetahuan bahwa suatu citra sudah dimanipulasi atau belum, maka diperlukan suatu teknik yang mampu menganalisa perubahan yang sudah terjadi di citra tersebut. Pada penelitian ini diterapkan salah satu metode untuk mendeteksi manipulasi citra jenis splicing.

Pada penelitian ini diterapkan salah satu metode untuk mendeteksi manipulasi citra jenis splicing. Pada manipulasi citra jenis ini, suatu objek dalam citra atau gambar, disalin ke tempat lain dalam citra yang berbeda (copy-move pada citra yang berbeda). Pada umumnya tujuan dari manipulasi jenis ini adalah untuk menambah objek dalam citra. Contoh, Pria asal Sydney Australia Dimitri de Angelis yang menipu para investor hingga 8.5 juta dollar atau kalua di rupiahkan lebihdari 85 miliar. Untuk meyakinkan para investor tersebut, de Angelis melakukan manipulasi citra sehingga dirinya tampak bersama dengan tokoh tokoh dunia seperti mantan Presiden Amerika Serikat Bill Clinton, Ratu Elizabeth II dari Inggris, Paus Johanes Paulus II dan Dalai Lama (Hoerr, 2015).

Beberapa penelitian lain sudah membahas metode pemecahan manipulasi jenis splicing. Pada penelitian yang dilakukan oleh (Das, 2016). untuk melakukan deteksi manipulasi citra jenis splicing menggunakan metode Gaussian blur.
Ketidak konsistenan Gaussian blur digunakan untuk menguji keaslian citra. Gaussian blur dari citra pertama dievaluasi dan standar deviasi yang diperoleh digunakan untuk mengaburkan citra. Hasilnya dapat digunakan untuk mendeteksi daerah yang ditempa yang sangat buram, tetapi citra dengan splicing di dalamnya kurang akurat terdeteksi dan algoritma ini bekerja dengan baik hanya dengan pemalsuan jenis Gaussian blur.

Pada paper yang ditulis (Fan, 2015) Menggabungkan lima algoritma yang digunakan untuk mendeteksi splicing. Secara umum, metode yang diusulkan menghasilkan akurasi lebih dari $67 \%$. Sementara pada penelitian yang dilakukan (Julliand, 2015). Menyoroti ketidak konsistenan noise lokal dalam pemindaian citra secara quadtree. Metode ini dapat mendeteksi splicing dalam citra digital mentah, namun pada area penyambungan yang kecil tidak mampu untuk mendeteksi splicing secara baik dan akurat.

Ada banyak metode yang digunakan untuk pemecahan masalah manipulasi jenis splicing, akan tetapi akurasi deteksi metode tersebut masih kurang. Oleh karena itu pada penelitian ini diterapkan salah satu metode untuk menyelsaikan masalah diatas dengan menggunakan metode deteksi tepi block JPEG terkompresi. Proses deteksi tepi block JPEG terkompresi dilakukan dengan mencari inkonsisten piksel bertetangga dari JPEG terkompresi berdasarkan perbedaan energi piksel pada batas block citra. Setelah itu citra dibagi dalam block 8x8 non-overlapping dengan asumsi ketika citra disimpan dalam format JPEG sehingga block $8 \times 8$ tersebut berupa block JPEG terkompresi dan kemudian menghitung perbedaan energi piksel pada batas block untuk setiap block. Dengan menggunakan metode ini nantinya hasil yang diharapkan akan mampu meningkatkan akurasi deteksi manipulasi splicing dengan baik dan akurat

\section{Metode Penelitian}

a. Desain

Desain tampilan antarmuka dari program yang akan dibangun, terdapat beberapa menu yang mempunyai fungsi pengolahan. Sistem deteksi manipulasi splicing ini dibangun dengan Aplikasi Matlab. Berikut adalah desain antarmuka system deteksi manipulasi splicing yang akan dibangun: 


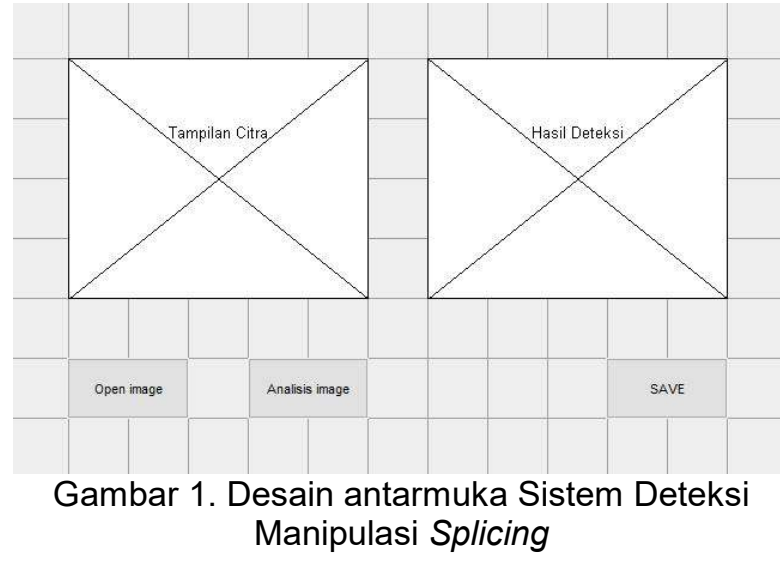

Penjelasan gambar 1 desain sistem deteksi manipulasi splicing, Open image adalah botton untuk memilih image yang akan dianalisis, tampilan citra layar untuk menampilkan hasil image yang sudah dipilih tadi, analisis image botton untuk analisa image, sedangkan hasil deteksi layar untuk menampilkan hasil dari analisis deteksi.

b. Penerapan Metode Deteksi Tepi

Penerapan metode deteksi tepi dilakukan untuk mencari inkonsisten piksel bertetangga dari JPEG terkompresi berdasarkan perbedaan energi piksel pada block. Berikut alur deteksi manipulasi splicing:

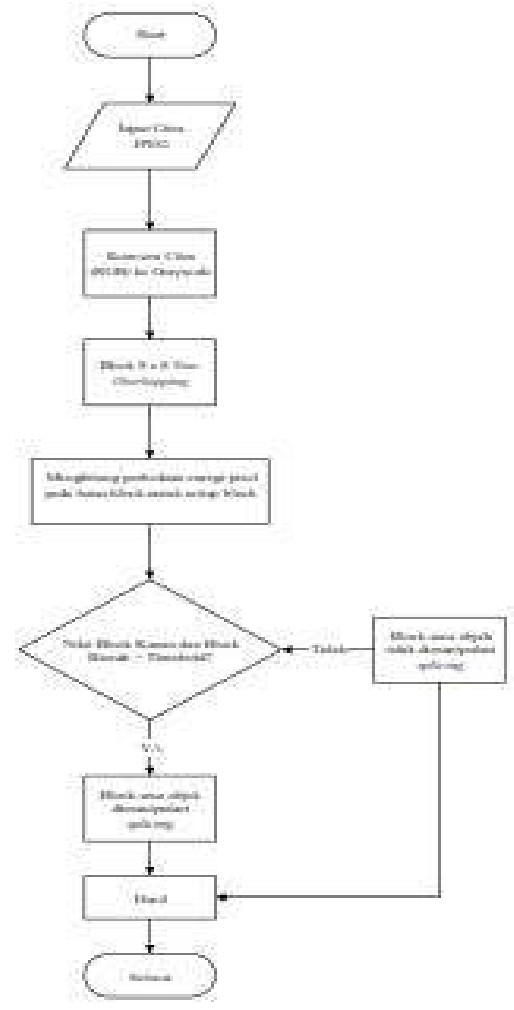

Gambar 2. Alur Deteksi Manipulasi Splicing
Gambar 2 Menunjukan proses yang dilakukan adalah dengan membagi gambar dalam block 8x8 non-overlapping dengan asumsi gambar splaicing ketika disimpan dalam format JPEG sehingga block $8 \times 8$ tersebut berupa block JPEG terkompresi. Lalu dihitung perbedaan energi piksel pada batas block untuk setiap block. Nilai yang didapat dibandingkan terhadap block dikanan dan block dibawahnya apabila kedua nilai tersebut lebih besar dari nilai threshold yang ditentukan maka block area objek tersebut sudah dilakukan manipulasi.

\section{c. Implementasi Sistem}

Implementasi adalah proses untuk memastikan bahwa sistem atau metode algoritma yang dibangun bebas dari kesalahan dan mudah digunakan oleh pengguna dalam hal ini seorang investigator. Untuk mendeteksi manipulasi splicing pada citra berekstensi JPEG menggunakan metode algoritma deteksi tepi block JPEG terkompresi.

\section{d. Pengujian}

Pengujian dilakukan dengan tujuan untuk mengetahui tingkat akurasi deteksi dari metode yang digunakan.

Tabel 1. Pengujian

\begin{tabular}{|c|c|c|c|}
\hline No. & Citra Asli1 & Citra Asli2 & $\begin{array}{c}\text { Hasil } \\
\text { Manipulasi } \\
\text { Pribad }\end{array}$ \\
\hline \multirow[t]{6}{*}{1} & & 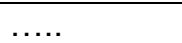 & . \\
\hline & $\begin{array}{l}\text { Hasil } \\
\text { Deteksi }\end{array}$ & $\begin{array}{l}\text { Hasil } \\
\text { Deteksi }\end{array}$ & Hasil Deteksi \\
\hline & & & \\
\hline & $\begin{array}{l}\text { Deskriptif } \\
\text { Akurasi }\end{array}$ & $\begin{array}{l}\text { Deskriptif } \\
\text { Akurasi }\end{array}$ & $\begin{array}{l}\text { Deskriptif } \\
\text { Akurasi }\end{array}$ \\
\hline & & ..... & $\ldots \ldots$ \\
\hline & Citra Asli1 & Citra Asli2 & $\begin{array}{c}\text { Hasil } \\
\text { Manipulasi } \\
\text { Internet }\end{array}$ \\
\hline \multirow[t]{4}{*}{2} & & 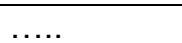 & $\cdots$ \\
\hline & $\begin{array}{l}\text { Hasil } \\
\text { Deteksi }\end{array}$ & $\begin{array}{l}\text { Hasil } \\
\text { Deteksi }\end{array}$ & Hasil Deteksi \\
\hline & $\begin{array}{l}\text { Deskriptif } \\
\text { Akurasi }\end{array}$ & $\begin{array}{l}\text { Deskriptif } \\
\text { Akurasi }\end{array}$ & $\begin{array}{l}\text { Deskriptif } \\
\text { Akurasi }\end{array}$ \\
\hline & & & \\
\hline
\end{tabular}

\section{Hasil dan Pembahasan}

Pada paper ini, kami mecoba mengambil contoh gambar yang asli dan gambar yang sudah dimanipulasi. Citra atau gambar tersebut dibagi menjadi beberapa bagian, masing-masing adalah gambar asli, gambar yang digunakan sebagai bahan percobaan untuk melakukan manipulasi splicing sebanyak 4 (empat) file gambar dengan 
hasil manipulasi 2 (dua) dimana 1 (satu) file gambar hasil manipulasi pribadi dan 1 (satu) file gambar manipulasi dari internet. Proses manipulasi splicing dilakukan dengan menggunakan Adobe Photoshop CC 2015 lalu disimpan dalam format JPEG dengan quality 5 (medium) skala photoshop. Dan untuk hasil manipulasi dari internet tidak dilakukan proses manipulasi apapun dibiarkan sesuai dengan aslinya.

Pengujian dilakukan dengan tujuan untuk mengetahui tingkat akurasi deteksi dari metode ayang digunakan. Berikut table 2. Menampilkan hasil dari pengujian yang sudah dilakukan.

Tabel 2. Hasil Pengujian

\begin{tabular}{|c|c|c|c|}
\hline No. & Citra Asli1 & Citra Asli2 & $\begin{array}{c}\text { Hasil } \\
\text { Manipulasi } \\
\text { Pribad }\end{array}$ \\
\hline \multirow[t]{6}{*}{1} & & & \\
\hline & $\begin{array}{l}\text { Hasil } \\
\text { Deteksi }\end{array}$ & $\begin{array}{l}\text { Hasil } \\
\text { Deteksi }\end{array}$ & $\begin{array}{l}\text { Hasil } \\
\text { Deteksi }\end{array}$ \\
\hline & 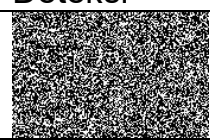 & Wxy & \\
\hline & $\begin{array}{l}\text { Deskriptif } \\
\text { Akurasi }\end{array}$ & $\begin{array}{l}\text { Deskriptif } \\
\text { Akurasi }\end{array}$ & $\begin{array}{l}\text { Deskriptif } \\
\text { Akurasi }\end{array}$ \\
\hline & $\begin{array}{l}\text { Tidak ada } \\
\text { objek yang } \\
\text { teridetifikasi } \\
\text { splicing }\end{array}$ & $\begin{array}{l}\text { Tidak ada } \\
\text { objek yang } \\
\text { teridetifikasi } \\
\text { splicing }\end{array}$ & $\begin{array}{l}\text { Berhasil } \\
\text { mendeteksi } \\
\text { objek yang } \\
\text { di } \\
\text { splicing }\end{array}$ \\
\hline & Citra Asli1 & Citra Asli2 & $\begin{array}{c}\text { Hasil } \\
\text { Manipulasi } \\
\text { dari } \\
\text { Internet }\end{array}$ \\
\hline \multirow[t]{5}{*}{2} & & & \\
\hline & $\begin{array}{l}\text { Hasil } \\
\text { Deteksi }\end{array}$ & $\begin{array}{l}\text { Hasil } \\
\text { Deteksi }\end{array}$ & $\begin{array}{l}\text { Hasil } \\
\text { Deteksi }\end{array}$ \\
\hline & 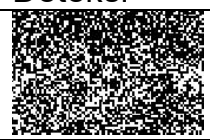 & a) 3 th & \\
\hline & $\begin{array}{l}\text { Deskriptif } \\
\text { Akurasi }\end{array}$ & $\begin{array}{l}\text { Deskriptif } \\
\text { Akurasi }\end{array}$ & $\begin{array}{l}\text { Deskriptif } \\
\text { Akurasi }\end{array}$ \\
\hline & $\begin{array}{l}\text { Tidak ada } \\
\text { objek yang } \\
\text { teridetifikasi } \\
\text { splicing }\end{array}$ & $\begin{array}{l}\text { Tidak ada } \\
\text { objek yang } \\
\text { teridetifikasi } \\
\text { splicing }\end{array}$ & $\begin{array}{l}\text { Tidak bisa } \\
\text { mendeteksi } \\
\text { objek yang } \\
\text { di } \\
\text { spilicing }\end{array}$ \\
\hline
\end{tabular}

\section{Kesimpulan}

Setelah melakukan beberapa hal terkait dengan pengujian dan analisis maka diperoleh beberapa kesimpulan sebagai berikut.

1. Metode deteksi tepi block JPEG terkompresi, berhasil diimplementasikan untuk mendeteksi manipulasi splicing pada citra berekstensi JPEG.

2. Hasil pengujian berupa manipulasi splicing berhasil mendeteksi objek citra yang dimanipulasi secara akurat dan baik.

3. Metode deteksi tepi block JPEG terkompresi ini mampu mendeteksi objek citra yang di splicing dengan baik dan akurat, tapi metode ini hanya bisa digunakan untuk mendeteksi citra yang belum diupload di internet.

\section{Daftar Pustaka}

M. J. Charpe, "Revealing Image Forgery through Image Manipulation Detection," no. Gcct, pp. 723-727, 2015.

A. Kashyap, M. Agarwal, and H. Gupta, "Detection of Copy-move Image forgery using SVD and Cuckoo Search Algorithm," 2017.

J. Tim Okezone, "Ini 3 Temuan Terbaru dari Kasus Saracen." 2017.

P. E. Kresnha, E. Susilowati, and Y. Adharani, "Pendeteksian manipulasi citra berbasis copy-move forgery menggunakan euclidian distance dengan single value decomposition," pp. 6-7, 2016.

I. W. S. Wicaksana, L. Aditya, M. Doring, F. Armansyah, R. A. Putra, and R. Adimansyah, "Pendeteksian Manipulasi Gambar Dari Metode Copy-Move EXACTMATCH," vol. 2008, pp. 21-24, 2016

A. U. Tembe and S. S. Thombre, "Survey of CopyPaste Forgery Detection in Digital Image Forensic," no. Icimia, pp. 248-252, 2017.

B. Li, T. Ng, X. Li, and S. Tan, "Revealing the Trace of High-Quality JPEG Compression Through Quantization Noise Analysis," vol. 10, no. 3, pp. 558-573, 2015.

D. Luo, W. Luo, R. Yang, and J. Huang, "Compression history identification for digital audio signal," pp. 1733-1736, 2012.

K. Hoerr, "Celebrity' fraudster Dimitri de Angelis appeals against sentence," 2015.

A. Das, A. Medhi, R. K. Karsh, and R. H. Laskar, "Image Splicing Detection using Gaussian or Defocus Blur," pp. 1237-1241, 2016.

Y. Fan, P. Carré, C. Fernandez-maloigne, and U. M. R. Cnrs, "IMAGE SPLICING DETECTION WITH LOCAL ILLUMINATION ESTIMATION," pp. 29402944, 2015. 
T. Julliand, V. Nozick, and H. Talbot, "Automated Image Splicing Detection from Noise Estimation in Raw Images," 2015. 